\section{The Use of the PCR to Quantitate Gene Expression}

\author{
William C. Gause and \\ Jeff Adamovicz
}

\author{
Department of Microbiology, \\ Uniformed Services University \\ of the Health Sciences, \\ Bethesda, Maryland 20814
}

Several techniques are currently available to measure changes in gene expression. These include the Northern blot, the RNase protection assay, in situ hybridization, and the reverse transcriptase-polymerase chain reaction (RTPCR). For many purposes, the Northern blot or the more sensitive RNase protection assay is sufficient to detect quantitative differences between samples. However, if the sample quantity is low or the target message is rare such that these techniques are no longer practical, the more sensitive quantitative RT-PCR can be used. In cases where comparisons have been possible, results from the RT-PCR assay are quite comparable to results from Northern blot analysis, ${ }^{(1)}$ slot-blot analysis, ${ }^{(2)}$ and in situ hybridization. ${ }^{(3)}$ In the RT-PCR method, RNA is initially reverse-transcribed to cDNA and the desired target cDNA species is amplified using specific primers. Less than 10 copies of target RNA are required for this procedure, and it has been successful when the RNA is isolated from a single cell. ${ }^{(4)}$ Because of this high sensitivity, the RT-PCR is being increasingly used to quantitate small but physiologically relevant changes in gene expression that would otherwise be undetectable. For example, in a recent study involving analysis of IL-4 gene expression after immunization with antigen, studies with blocking anti-IL-4 antibodies had demonstrated previously the importance of elevated IL-4 in the response, but neither Northern blot analysis nor in situ hybridization could detect corresponding elevations in IL-4 gene expression. A quantitative RT-PCR was developed to analyze IL-4 cytokine gene expression. The quantitative RT-PCR showed that there was a $150 \times$ increase in IL- 4 message in spleens from immunized mice. ${ }^{(5)}$ Later studies using an ELISPOT assay, which measures protein secretion by individual cells, confirmed that the marked increase in IL-4 message was correlated with marked increases in IL-4 secretion. ${ }^{(6)}$ The advantage of the gene expression assay in this system is that tissue and cells taken directly from the animal can be measured. In contrast, protein assays usually require in vitro cell culture, in some cases with mitogens, often resulting in the production of cytokines not originally produced by the cells in vivo.

\section{THE PLATEAU EFFECT}

The sensitivity of RT-PCR is a result of a chain reaction, where the products from one cycle of amplification serve as substrates for the next, resulting in an exponential increase in product. Theoretically, the amount of product doubles during each cycle of the PCR reaction, but, in actuality, beyond a certain number of cycles, the efficiency of amplification decreases with increasing cycle number, resulting in the plateau effect as shown in Figure 1.

A number of factors may cause the plateau effect, including (1) degradation of nucleotides or primers, (2) inactivation of the DNA polymerase enzyme ( $\mathrm{Taq}$ has a half-life of only $40 \mathrm{~min}$ at $95^{\circ} \mathrm{C}$ ), (3) reassociation of singlestranded PCR fragments before primers can anneal or be extended, (4) substrate excess where there is more DNA than the amount of enzyme available to replicate it in the allotted polymerization time, (5) competition by nonspecific amplification products, and (6) accumulation of inhibitors of polymerase activity, such as pyrophosphates. The number of PCR cycles at which the plateau effect occurs varies greatly with the particular DNA sequence being amplified. Length, GC content, and the presence of any secondary structure in the sequence to be amplified are all important, as is the initial total quantity and concentration of the target DNA. As a result, the number of cycles at which the plateau effect occurs must be individually and empirically determined for each target sequence. This is particularly important if one plans to attempt a quantitative PCR; in the past this has led to considerable confusion. Amplifying various samples of target cDNA at a high number of cycles, for example, 35, is useful for determining the presence or absence of 


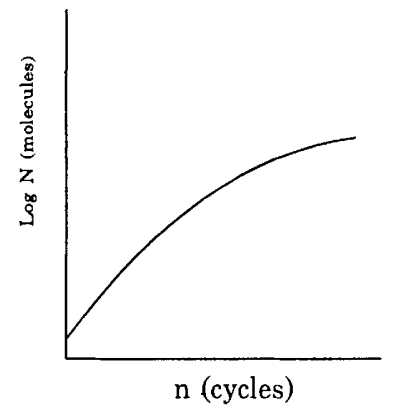

n (cycles)
FIGURE 1 Equation 1: $N=N_{0}(1+E)_{n}$, where $N=$ the number of amplified molecules, $N_{0}=$ the initial number of amplification molecules, and $E=$ the amplification efficiency. The relationship between product amplification and the number of cycles during PCR. A linear relationship occurs initially, followed by the plateau effect, where increases in cycle number result in proportionally smaller increases in product. Although $E$ varies between target cDNAs even at early cycles, it inevitably decreases at higher cycle numbers.

a given target ${ }^{(7,8)}$ but should not be used to compare differences in target quantities of $<100$-fold. This is because differences observed in the amount of detectable product after the plateau effect has been reached (an exception may be competitive PCR as will be discussed later) are frequently artifacts and on further study may show little relationship to the quantity of starting target material.

\section{SOURCES OF VARIATION}

The RNA purification procedure is a major source of variation in quantitative RT-PCR. Several different techniques are available, and they are reviewed in depth elsewhere; ${ }^{(9)}$ the technique that we use is included in the Appendix. Both total RNA and poly(A)-selected mRNA are commonly used because the PCR's sensitivity can be adjusted to either. However, these two different RNA populations should not be included in the same assay because the increased concentration of target in poly $(\mathrm{A})$-selected mRNA makes comparisons to total RNA inappropriate. A disadvantage of poly(A)-selected mRNA is that it can vary greatly in terms of the ratio of mRNA to total RNA, thereby contributing another source of variation. Whether one uses total RNA or mRNA for the starting material, because of the relatively high instability of RNA and the ubiquitous presence of RNases, degradation can be a serious problem. Because spectrophotometric analysis cannot distinguish between undegraded and degraded RNA, it is thus necessary to control for this additional source of variation by using a "housekeeping" gene. A housekeeping gene is a constitutively expressed gene that theoretically does not vary following activation or proliferation of a cell. Several different housekeeping genes are used, including $\beta$-actin, hypoxanthine-guanine phosphoribosyl transferase (HPRT), and glyceraldehyde-3-phosphate dehydrogenase (GAPDH). With each of these, some changes in gene expression may be detected following activation of particular cell types, and, consequently, it should be determined empirically which housekeeping gene changes the least in the particular system being investigated. Generally, the housekeeping gene selected should not vary in its expression more than two- to threefold between treatment groups and controls.

Besides the RNA purification step, reverse transcription of RNA to cDNA is also a source of variation and error inherent in the RT-PCR technique. Generally, two reverse transcriptases are used, avian myeloblastosis virus (AMV) and Moloney murine leukemia virus (Mo-MLV). Each has its advantages and disadvantages. The most commonly used enzyme for the RT-PCR assay is Mo-MLV. This enzyme has weak RNase $\mathrm{H}$ activity, which favors synthesis of long cDNAs; RNase H recognizes the primer-template mRNA hybrids as substrates. Recently, recombinant forms of Mo-MLV have been developed that are RNase $\mathrm{H}^{-}$, eliminating the competition between degradation of the template mRNA and the initiation of cDNA synthesis. AMV has the disadvantage 


\section{IIIIIManual Supplement}

in that it has high RNase $\mathrm{H}$ activity, but because the optimal temperature for the enzyme reaction is $42^{\circ} \mathrm{C}$ and not $37^{\circ} \mathrm{C}$, as with $\mathrm{Mo}-\mathrm{MLV}, \mathrm{AMV}$ is preferred if the target region has considerable secondary structure. A recently developed recombinant $\mathrm{RNase} \mathrm{H}^{-}$reverse transcriptase (BRL, Gaithersburg, MD) apparently also can be used at $42^{\circ} \mathrm{C}$. The higher reaction temperature is more likely to destabilize secondary structure reducing the likelihood that the reverse transcriptase reaction will be inhibited. ${ }^{(9,10)}$ In the Appendix a typical reverse transcriptase reaction is included that uses an $\mathrm{RNase}^{-} \mathrm{Mo-MLV}$. Random primers prime the reverse transcriptase in this protocol; alternative primers include oligo(dT) or the downstream antisense PCR primer. We and others have found empirically that random primers give consistent results and high overall yields of amplified target sequence, ${ }^{(5,11,12)}$ but both oligo(dTs) and antisense PCR primers have also been used successfuly. ${ }^{(12,13)}$

The selection of primers for the PCR amplification is usually accomplished by downloading a cDNA sequence into a program that uses specific criteria for the selection of the appropriate cDNA region to be amplified and for the selection of the flanking primers. ${ }^{(5,14)}$ These criteria are discussed in the previous articles in this supplement and will not be discussed in detail here. Generally, primers are selected that range from 18 to $25 \mathrm{bp}$, have a $50 \%$ GC content, and amplify a region ranging from 200 to $400 \mathrm{bp}$. An additional rule fairly unique to primers used for RT-PCR involves selection of a primer set that spans an intron so large that the gene itself cannot be amplified. If this is not possible, then the primer set should at least span an intron large enough that product from the gene and the cDNA can be easily distinguished on an agarose gel. With this additional criterium, DNA contamination, common in RNA preparations, will not contribute to the amount of target sequence recognized by the cDNA-specific primers. If the genomic structure is not known, primers can be selected that are separated by 300 to 400 bases in the coding region of the gene, as exons greater than this size are rare in vertebrates. If the gene encoding the target mRNA species lacks introns, as is the case with interferon- $\alpha$ (IFN- $\alpha$ ), a thorough DNase treatment of the RNA is necessary and reactions without the addition of reverse transcriptase as controls of genomic DNA contamination are required. ${ }^{(15,16)}$

Once cDNA can be produced from purified RNA in a uniform and reproducible manner, then, using the appropriate primers, a quantitative PCR can be developed. The purpose of the quantitative RT-PCR is to deduce, from the final quantity of PCR product, the initial number of target molecules or, perhaps more realistically, relative differences in starting target molecules between experimental samples. Currently, there are a number of different approaches used; several of the more popular ones are discussed here in some detail. These approaches can be generally divided into two categories: noncompetitive and competitive. Each has advantages and disadvantages, and careful consideration should be undertaken before commitment is made to one approach or the other.

\section{NONCOMPETITIVE RT-PCR}

The noncompetitive RT-PCR relies on the observation, now well established, that prior to the onset of the plateau effect there is a linear relationship between the quantity of input RNA and final product during PCR amplification. ${ }^{(5,11,13,15-20)}$ The procedure that we use is included in the Appendix. To determine the number of cycles at which this linear relationship occurs, one should initially select a sample of RNA expressing high levels of target mRNA. One should not add exogenous target to the RNA sample but, instead, should use a sample where endogenous target gene expression is high but not two- 
to threefold more than the highest levels one would expect in an actual experiment. Five to 10 serial dilutions of this sample, commonly $1: 2$, are made to span close to a 1000-fold concentration range. Complete sets of these dilution series are then amplified at one of several different cycle numbers. We have found that with many cytokines the cycle number at which a linear relationship is detected between input RNA and final product is between 18 and 25 cycles. Typically, the total RNA is diluted in buffer. Although a linear relationship is detected under these circumstances, ${ }^{(5)}$ the possibility exists that the RT-PCR technique is nonetheless nonquantitative because decreases in the efficiency of priming may occur as mRNA specific for a given cytokine is diluted with mRNA specific for other proteins. We have directly tested this by diluting total RNA from tissue expressing high amounts of IL- 4 mRNA in total RNA from tissue that expresses negligible amounts of IL- 4 mRNA, so that the quantity and concentration of RNA remained the same, but the amount of RNA from tissue that expressed high IL- 4 mRNA levels decreased by $50 \%$ with each successive dilution. As shown in Figure 2, a linear relationship between input RNA and final RT-PCR product was maintained throughout the dilution range. This indicates that differences in relative concentrations of target message can be quantitated when total RNA concentrations remain constant.

Often, the low cycle number required to obtain the linear relationship shown in Figure 2 does not produce sufficient product for detection on UV transilluminators following ethidium bromide staining. To increase the sensitivity of detection, the product can be Southern blotted and probed with a suitable end-labeled oligonucleotide, as was done in Figure 1. It is best to use an oligonucleotide that does not correspond to either of the original primers used for amplification. This adds an extra level of specificity to the procedure: If the primers caused any spurious nonspecific DNA amplification, often identified as unpredicted bands on an agarose gel, the resultant product will not be bound by the specific probe. Using this procedure one can obtain three levels of specificity: (1) amplification of product with specific primers; (2) correspondence of actual product size to original estimated product size; and (3) hybridization of product with internal probe not corresponding to either primer. Also, the low cycle number reduces artifacts such as nonspecific am-

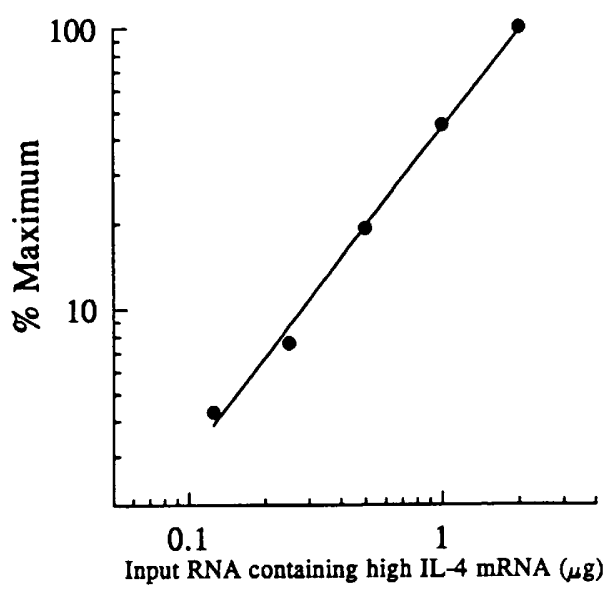

FICURE 2 Autoradiograph (below) and densitometric analysis (above) of IL-4 RT-PCR signal as a function of the amount of input RNA. 
plifications that could pose major obstacles at higher cycle numbers. Another technique for detecting product involves incorporation of labeled nucleotides into PCR products that are then resolved by gel electrophoresis. However, this approach is often associated with trace amounts of unincorporated label that can produce a trail of label throughout the lane of an electrophoretic gel. One can also use labeled primers at the beginning of the assay or as a final PCR step with a new internal labeled primer annealed to one strand of the PCR product and extended using Taq polymerase. However, both approaches often result in considerable background radioactivity and rarely give signals as well-defined and quantifiable as is observed with the Southern blot. ${ }^{(21,22)}$

Currently, an increasing number of investigators are using radioimaging and direct quantitation systems for measurement of radiolabeled product. Autoradiography and densitometric quantitation is more cumbersome, particularly because it has a dynamic range of only two to three orders of magnitude, whereas systems such as AMBIS or PhosphorImagers have ranges of five orders of magnitude or greater. Recently, nonradioactively labeled probes have been used successfully for Southern blot analysis of PCR products and subsequent quantitation of changes in cytokine gene expression with a video densitometer. ${ }^{(19)}$ Also, an ELISA-based quantitative RT-PCR assay has been developed that uses an ELISA reader to measure amplified products. ${ }^{(23)}$ For safety reasons, these approaches using nonradioactive materials will probably become increasingly popular.

It is important to include an internal standard in the quantitative RT-PCR assay. DNA standards have been used for the quantification of RNA targets, but in these instances variation in reverse transcriptase efficiency, an important source of variability, is not taken into account. Two types of internal standards are commonly used: an exogenous fragment added to the amplification reaction, or an endogenous sequence or gene transcript that is normally present in the sample. If an exogenous fragment is used, it can be an mRNA standard added to the target sample and amplified simultaneously with the endogenous target in a single PCR reaction. The purpose of the exogenous internal standard is to allow detection of differences in the amplification efficiency ( $E$ in Fig. 1 ) between reaction tubes within an assay or between assays. A known amount of standard is added to each sample and quantitated after amplification. If differences in the amount of standard product are detected between reaction tubes, then the product derived from the target sequence is normalized to the standard in its respective tube. Although $E$ has been considered a serious problem in the past, ${ }^{(24,25)}$ it was partly a result of inferior thermal cyclers that exhibited temperature cycling variations from one well to another. With the advent of better machines this has become less of a problem. For several thermal cycling machines currently available, the amount of variation from well to well has been reported by the manufacturers to be $<10 \%$. We have confirmed this in our laboratory by simultaneously amplifying target mRNA in all the wells of a thermal cycler at the number of cycles where the relationship between input RNA and final signal was linear. ${ }^{(26)}$ However, although addition of an exogenous sequence may not be necessary where samples are compared within the same assay, it is still useful if one attempts to compare samples in different experiments. Also, the exogenous standard can be used in noncompetitive assays to quantitate the absolute level of target or cDNA in the original sample as was done by Wang et al. ${ }^{(27)}$ Although apparently successful, absolute quantitation of PCR product relies on the assumption that the value of $E$ is the same for both the target and standard mRNAs; this has to be determined empirically because even slight differences in PCR product or primer sequence may affect the amplification efficiency. In many cases, however, quantitation of relative differences be- 
tween samples in an experiment is most important, and the extra steps involved in attempting to measure absolute levels are unnecessary.

An important alternative to the exogenous internal standard is the use of an endogenous sequence as the internal standard. Typically, a housekeeping gene is used, such as $\beta$-actin, HPRT, or GAPDH. ${ }^{(5,15,28)}$ The endogenous standard permits detection of relative differences in the integrity of individual RNA samples. Even if the same quantity of RNA is used for each preparation, the final quantity of product may be greatly affected by differences in RNA integrity and the presence of inhibitors of RT. This is a particular problem because the degree of RNA degradation can vary significantly between samples within a given experiment and, as mentioned earlier, RNA degradation is not detectable spectrophotometrically. There are essentially two approaches to detect the variation in RNA degradation between samples. One approach involves electrophoresing 5-10 $\mu$ g of total RNA on an agarose gel and visualizing via ethidium bromide staining whether the ribosomal bands are intact. This procedure requires a large quantity of total RNA and, as a result, is often not practical. The second approach involves amplification of housekeeping mRNA from the same RNA preparation used for target amplification. Coamplification of the target and the housekeeping mRNA sequences are done in the same tube or different tubes. Frequently, coamplification in the same tube is not practical, because the housekeeping gene is expressed at such high levels in the RNA mixture that its amplification inhibits the amplification of the target mRNA. ${ }^{(29-31)}$ In these cases it is usually necessary to amplify in separate tubes, although one can also wait until later stages of the amplification before adding the primers that amplify the endogenous standard primers. ${ }^{(32)}$ Either way, with endogenous standards, variations in initial target RNA resulting from RNA degradation can be controlled for by simply normalizing the final target product quantity to the amount of housekeeping gene product. For example, if two target PCR products, A and B, are quantitated at values of 50 and 100, respectively, and the corresponding housekeeping gene products are at 25 and 50, the final normalized values of $A$ and $B$ are both 2 , demonstrating no difference between $\mathrm{A}$ and $\mathrm{B}$ with regard to expression of the particular target gene measured.

An exogenous internal standard cannot be used to detect differences in mRNA integrity. Although useful for measuring differences in amplification efficiency $(E)$ during PCR, it is not a substitute for an endogenous standard. Endogenous standards also correct for differences in RNA purity, resulting from DNA or protein contamination. Such contamination may result in misleading spectrophotometric readings and, consequently, incorrect concentration determinations. In summary, the quantitative RT-PCR technique thus requires the use of an endogenous standard. Other endogenous standards besides typical housekeeping genes are also used. For example, if measurements are made of target gene expression from a particular cell subpopulation, a gene constitutively expressed by that subpopulation may be used. For example, TCR $\mathrm{C} \alpha$ or $\mathrm{C} \beta$ has been used as an endogenous internal standard in the quantitation of changes in TCR V $\beta$ expression. ${ }^{(33-35)}$

\section{COMPETITIVE RT-PCR}

Competitive RT-PCR was developed to quantitate absolute values of target RNA. The procedure relies on the use of an external standard that "mimics" or closely imitates the target RNA species with respect to primer binding and other variables affecting PCR amplification. This is an important difference from the exogenous internal standard used in the noncompetitive assay, where the standard primer set can amplify a completely different target than the experimental target mRNA. In the competitive assay, the standard is sim- 
ilar enough to the target that competition with target occurs and, ideally, the experimental and standard target sequences amplify with the same efficiency ( $E$ in Fig. 1) but can be distinguished from each other following agarose gel electrophoresis. These standard fragments fall into two categories: homologous and heterologous competitor fragements. ${ }^{(24,30,36,37)}$ Homologous fragments differ only slightly from the target sequence with the addition of a unique restriction site or the presence of an additional sequence such as an intron that increases the molecular weight of the standard. Recently, several rapid PCR-based techniques have been used to develop homologous standards. One potential problem with this sort of standard is the formation of heteroduplexes between the standard and target sequences during the amplification process - an artifact that could interfere with quantitation. In contrast, heterologous competitor fragments differ from the target, except for the flanking primer-template regions, which are identical. Thus, heteroduplex formation cannot occur, and slight differences in the target and primer sequence can be easily created.

The competitive RT-PCR assay is usually performed by titrating a known quantity of the standard mRNA target against a constant amount of the experimental mRNA target. The concentration at which product from the standard target equals the product produced from the experimental target is taken to be the starting concentration of the experimental mRNA. Given the differences between PCR mimics and the experimental target, particularly with heterologous standards, it is essential to determine empirically whether the target and mimic sequences amplify with similar efficiencies. To do this, one can plot the log of the product against the cycle number for the experimental and the standard target. The similarity of the slopes of the linear portion of the resulting two curves is indicative of the similarity of the amplification efficiency. Successful PCR mimics for a large number of genes have been developed, and many of these are commercially available from companies, including Clontech (Palo Alto, CA).

It has been suggested that the nature of the competitive PCR makes it possible to obtain useful data after the reaction has reached the plateau phase. This can be a considerable advantage because quantitation can be performed by simple agarose gel electrophoresis of ethidium bromide-stained PCR product. However, others caution that even the competitive PCR technique may not work well when the product is measured well after the plateau phase, particularly when the sequences of the target and standard molecules are different, with the exception of the primer sequences, that is, heterologous. ${ }^{(38)}$

A major source of variability usually not controlled for in competitive RT-PCR assays is RNA purity and RNA integrity. In assays where DNA instead of RNA standards are used, ${ }^{(37,39,40)}$ there is also no control for reverse transcriptase yield and uniformity. Because the nature of the RNA preparation is a major source of variation in any assay of gene expression, the reliability of this approach without additionally using endogenous internal standards is suspect. However, as mentioned earlier, because most investigators are interested in quantitating relative differences between control and treatment groups, the necessity for exogenous mimic RNA standards to determine absolute levels may be limited.

In summary, RT-PCR is a powerful technique for the quantitation of changes in gene expression. Several different approaches are widely used, including noncompetitive and competitive assays. With both assays, it is paramount to include endogenous standards, and if one plans to compare samples between assays or if the amplification efficiency varies significantly from well to well of the thermal cycler being used, it is advisable to also include external RNA standards. One should also standardize each of the procedures involved in the RT-PCR technique as much as possible, optimiz- 
ing each step including (1) RNA isolation, (2) the reverse transcriptase reaction, (3) PCR amplification, (4) Southern blotting and hybridization, and (5) quantitation of product. Included in the Appendix is a protocol describing the technnique we have used for quantitating differences in cytokine gene expression. As different laboratories become experienced with the quantitative RT-PCR technique we expect it to be used increasingly in gene expression studies directed toward understanding immunity, development, differentiation, transformation, and tumorigenesis.

\section{APPENDIX}

\section{RT/PCR PROTOCOL}

\section{RNA Isolation}

Modification of the RNAzol B method is from Cinna Scientific, Inc. (Friendswood, TX).

\section{Tissue Preparation}

The approximate weight of any tissue samples to be studied should be determined. RNAzol should then be distributed to polypropylene tubes at $2 \mathrm{ml}$ of RNAzol per $100 \mathrm{mg}$ of tissue. The RNAzol should be kept cold and protected from light; also, great care should be taken when handling the RNAzol as it is highly caustic. The tissue sample should be placed in RNAzol and thoroughly homogenized. The sample can then be snap-frozen in liquid nitrogen and stored at $-70^{\circ} \mathrm{C}$ for future extraction.

RNA Extraction Frozen homogenates should be thawed for $\sim 5 \mathrm{~min}$ in a $37^{\circ} \mathrm{C}$ water bath. Add $0.2 \mathrm{ml}$ of a 24:1 mixture of chloroform/isoamyl alcohol for every $2 \mathrm{ml}$ of homogenate, and shake the samples vigorously for $15 \mathrm{sec}$. Let the samples sit on ice for $5 \mathrm{~min}$. Centrifuge the samples for $15 \mathrm{~min}$ in a refrigerated centrifuge $\left(4^{\circ} \mathrm{C}\right)$ at $12,000 \mathrm{~g}$. Carefully remove the aqueous (top) phase that contains the RNA and transfer it to another tube; store on ice. Care must be taken to avoid the white interphase layer, as this contains protein that will hamper your ability to quantify the RNA.

RNA Precipitation To each sample, add a volume of cold isopropanol that is equal to the volume of your aqueous phase. Mix the tubes gently, and store the samples for $15 \mathrm{~min}$ on ice. Centrifuge the samples for $15 \mathrm{~min}$ at $4^{\circ} \mathrm{C}$ and $12,000 \mathrm{~g}$. The RNA should form a whitish/yellowish pellet at the bottom of the tube.

RNA Washing Carefully decant the isopropanol. Wash the RNA pellet by adding a volume of cold $75 \%$ ethanol and resuspend the RNA pellet by shaking or pipetting. Centrifuge the sample for $8 \mathrm{~min}$ at $4^{\circ} \mathrm{C}$ and $12,000 \mathrm{~g}$. Carefully decant the ethanol and dry the pellets by air or under vacuum. Vacuum drying is more expedient, but care should be taken not to overdry the pellet.

RNA Quantification The RNA pellets should be solubilized in $20-50 \mu$ l of distilled, deionized water. It is usually helpful to freeze and thaw the samples to increase solubility. The product can be quantified spectrophotometrically by measuring the $\mathrm{OD}_{260} / \mathrm{OD}_{280}$ of an aliquot. The $260 / 280$ ratio should be 1.8 or above. If the ratio is low, the sample should be reextracted.

\section{Reverse Transcription}

The reverse transcriptase reaction described below is based on a starting concentration of $3.6 \mu \mathrm{g}$ of total RNA. 
Prepare a master mix based on the number of samples you have with components in the following concentrations:

Pharmacia (San Diego, CA) deoxynucleotide triphosphates

(2.5 mM each dNTPs)

$2.5 \mu 1$

GIBCO BRL (Gaithersburg, MD)

$0.1 \mathrm{M}$ dithiothreitol

$5.0 \mu 1$

Promega (Madison, WI)

RNasin (4000 U/ $/$ l)

$0.5 \mu 1$

Boehringer Mannheim (Indianapolis, IN)

random primers $(n=6)(20-40 \mathrm{U} / \mathrm{ml})$

RNA diluted with distilled/deionized $\mathrm{H}_{2} \mathrm{O}$ )

$2.0 \mu \mathrm{l}$

$8.8 \mu 1$

Total volume

$18.8 \mu l$

Heat the above mixture to $70^{\circ} \mathrm{C}$ for $5 \mathrm{~min}$ and then quench on ice. Centrifuge the samples briefly. To each sample, add $6.2 \mu \mathrm{l}$ of the mix, below.

GIBCO BRL RT storage buffer

GIBCO BRL RT (200 U/ $\mu$ l)

Final volume
$5.0 \mu \mathrm{l}$

$1.2 \mu l$

$25.0 \mu l$

Incubate the mixture at $37^{\circ} \mathrm{C}$ for $60 \mathrm{~min}$, denature at $90^{\circ} \mathrm{C}$ for $5 \mathrm{~min}$, and quench on ice for $5 \mathrm{~min}$. Store samples at $-70^{\circ} \mathrm{C}$.

\section{PCR}

The reaction described below is based on using $2.5 \mu \mathrm{l}$ of reverse transcriptase reaction product (cDNA).

\section{Prepare a Master Mix}

Based on the number of samples you have, add components in the following concentrations:

Pharmacia deoxynucleotide triphosphates

( $2.5 \mathrm{~mm}$ each mix of $10 \mathrm{~mm}$ dNTPs)

$4.0 \mu \mathrm{l}$

Promega Taq DNA polymerase buffer A

$5.0 \mu \mathrm{l}$

Promega $\mathrm{MgCl}_{2}(25 \mathrm{~mm})$

$3.0 \mu l$

Promega Taq DNA polymerase (5 U/ $\mu \mathrm{l}$ )

$0.2 \mu l$

Sense oligo primer $(0.2 \mu \mathrm{g} / \mu \mathrm{l})$

$2.0 \mu \mathrm{l}$

Antisense oligo primer $(0.2 \mu \mathrm{g} / \mu \mathrm{l})$

$2.0 \mu \mathrm{l}$

cDNA (from reverse transcriptase reaction)

$2.5 \mu \mathrm{l}$

Distilled, deionized $\mathrm{H}_{2} \mathrm{O}$

$31.3 \mu \mathrm{l}$

Final volume

$50.0 \mu l$

After mixing and spinning the PCR mixture down, overlay $50 \mu l$ of mineral oil.

PCR cycle conditions

Denature samples for $5 \mathrm{~min}$ at $94^{\circ} \mathrm{C}$.

Cycles: denaturing at $94^{\circ} \mathrm{C}$ for $45 \mathrm{sec}$ annealing at $53^{\circ} \mathrm{C}$ for $1 \mathrm{~min}$ extension at $72^{\circ} \mathrm{C}$ for $2 \mathrm{~min}$

Final extension at $72^{\circ} \mathrm{C}$ for $7 \mathrm{~min}$.

Soak at $4^{\circ} \mathrm{C}$.

Samples can be stored at $4^{\circ} \mathrm{C}$ for several months. 


\section{Southern Blotting}

Prepare Agarose Gel

For the purpose of transferring PCR product to nylon membranes, a 300-ml gel works best. This gel should be a $1 \%$ agarose-TBE gel with ethidium bromide prepared as follows: 3 grams of agarose heated/dissolved in $270 \mathrm{ml}$ of distilled water. Add $30 \mathrm{ml}$ of $10 \times \mathrm{TBE}$ and $30 \mu \mathrm{l}(10 \mu \mathrm{g} / \mu \mathrm{l})$ of ethidium bromide. Cool to $50^{\circ} \mathrm{C}$ and pour.

\section{Prepare PCR Samples}

For our detection system, phosphorimaging, we find that $9 \mu$ works best. Other detection methods that are not as sensitive may require a larger aliquot of the PCR reaction for transfer. Carefully remove $9 \mu$ l of the PCR product, and add to another tube taking care not to transfer any of the mineral oil. Add $1 \mu \mathrm{l}$ of loading buffer to the samples, and heat to $65^{\circ} \mathrm{C}$ for $5 \mathrm{~min}$. Quench the samples on ice, and spin them down; load the gel. After loading, add $1 \times \mathrm{TBE}$ buffer and run the gel at $120 \mathrm{~V}$ for 20-30 min.

\section{Blotting}

1. Denaturing. $(1 \times$ solution: $1.5 \mathrm{M} \mathrm{NaCl}, 0.5 \mathrm{M} \mathrm{NaOH}$ at $\mathrm{pH} 13)$. Slosh the gel for $25 \mathrm{~min}$ in this solution, decant and replace with fresh solution and repeat.

2. Rinse twice with distilled water.

3. Neutralize. (1.5 M NaCl, $1 \mathrm{M}$ Tris- $\mathrm{HCl}$ at $\mathrm{pH} 7.5)$. Slosh the gel for $15 \mathrm{~min}$ in this solution, decant and replace with fresh solution and repeat.

4. Rinse twice with distilled water.

5. Saturate. $(20 \times$ solution SSPE at $\mathrm{pH} 7.4)$. Slosh the gel for $30 \mathrm{~min}$ in this solution.

While the gel is in $20 \times$ SSPE, prepare the following: Soak a Nytran nylon membrane $(0.2 \mu \mathrm{m})$, from Schleicher \& Schuell $(S \& S)$, in distilled water. In $10 \times$ SSPE, soak two pieces of S\&S GB002 thin blotting paper. In $5 \times$ SSPE, soak one piece of $S \& S$ GB004 thick blotting paper. Set these items up to allow for at least a 30-min soak. Remove the gel, and invert it so that the bottom is facing up. Place the Nytran so that all of your samples are covered, and exclude all air bubbles. Cut away, and discard any excess agarose. Place the GB002 blotting papers (presoaked in 10× SSPE) on top followed by the GB004 paper (presoaked in $5 \times$ SSPE). Add 2-3 inches of dry GB004 blotting paper, and top with a hard metal or plastic tray followed by two 1-liter bottles of water. The transfer is completed overnight but may sit for up to $48 \mathrm{hr}$.

\section{Prehybridization}

After the transfer to Nytran is completed, the DNA must be attached to the membrane. This is accomplished by UV light. The blot is placed in a UV cross-linker with the side that was in contact with the gel facing up and expose it to $1200 \mathrm{~J}$ of UV eneroy. Make sure that you mark the blot with an indelible marker as to the approximate band position and orientation. For each blot, you will need $10 \mu$ l of prehybridization fluid with salmon sperm DNA (S.S. DNA) as described below. Prehybridization solution is stored at $-20^{\circ} \mathrm{C}$ without S.S. DNA. The recipe for $100 \mu \mathrm{l}$ is as follows:

$20 \times$ SSPE

$100 \times$ Denhardt's

$10 \%$ SDS

Distilled water
$30 \mathrm{ml}$ (final conc. $=6 \times)$

$10 \mathrm{ml}$ (final conc. $=10 \times$ )

$10 \mathrm{ml}$ (final conc. $=1 \times)$

$50 \mathrm{ml}$ 
Add S.S. DNA at a concentration of $50 \mu \mathrm{g} / \mathrm{ml}$. Denature the S.S. DNA before adding it to the prehybridization solution by heating the required amount of S.S. DNA $\left(\sim 50 \mu\right.$ l of stock) to $95^{\circ} \mathrm{C}$ for $5 \mathrm{~min}$ and then quenching on ice. Prewarm the prehybridization solution to $42^{\circ} \mathrm{C}$. Place the blot in a sealable food storage bag or other suitable container. Add the S.S. DNA to the prehybridization solution, and then add the mixture to the blot and seal the bag or container. If a bag is used, special care must be taken to exclude air bubbles. Place the bag or container in a $42^{\circ} \mathrm{C}$ water bath or oven and shake for $5 \mathrm{hr}$.

\section{Hybridization}

This procedure is described for use with end-labeled oligonucleotide probes. Proper procedures for handling radioactive materials should be followed.

1. Probe preparation.

Prepare fresh $1 \times$ probe buffer:

$\begin{array}{lc}1 \mathrm{M} \text { Tris }(\mathrm{pH} 7.6) & 5 \mu \mathrm{l} \\ 2 \mathrm{M} \mathrm{MgCl} & 0.5 \mu \mathrm{l} \\ 0.5 \mathrm{M} \text { dithiothreitol } & 1 \mu \mathrm{l} \\ \text { Distilled water } & 3.5 \mu \mathrm{l} \\ \quad \text { Total } & 10.0 \mu \mathrm{l} \\ \text { Prepare probe reaction mix: } & \\ \text { Probe buffer } & 2.5 \mu \mathrm{l} \\ \text { Probe }(0.2 \mu \mathrm{g} / \mu \mathrm{l}) & 2.0 \mu \mathrm{l} \\ \text { Pharmacia T4 kinase } & 1.0 \mu \mathrm{l} \\ \text { Distilled water } & 9.5 \mu \mathrm{l} \\ \text { [2] } \mathrm{PTP}(10 \mu \mathrm{Ci} / \mu \mathrm{l}) & 10.0 \mu \mathrm{l} \\ \text { Total } & 25.0 \mu \mathrm{l}\end{array}$

Incubate at $37^{\circ} \mathrm{C}$ for $40 \mathrm{~min}$. After the incubation is complete, separate the nonincorporated label with a G-25 Sephadex spin column $\left(5^{\prime} \rightarrow 3^{\prime}\right)$. Determine the specific activity of your probe by liquid scintillation.

2. Hybridization solution is stored frozen at $-20^{\circ} \mathrm{C}$. A recipe for $100 \mathrm{ml}$ is listed below:

$\begin{array}{ll}20 \times \text { SSPE } & 30 \mathrm{ml} \text { (final conc. }=6 \times \text { ) } \\ 10 \% \text { SDS } & 10 \mathrm{ml} \text { (final conc. }=1 \times \text { ) } \\ \text { Distilled water } & 60 \mathrm{ml}\end{array}$

Preheat the solution to $49^{\circ} \mathrm{C}$. Open the bag or container with the blot and pour off the prehybridization solution. Add $15 \times 10^{6} \mathrm{cpm}$ of the probe to 10 $\mathrm{ml}$ of hybridization solution, mix, and then add to the blot. Reseal the bag or container and incubate at $49^{\circ} \mathrm{C}$, while shaking, overnight.

\section{Washing}

Low-stringency Wash

Remove the hybridization solution and discard properly. Preheat the lowstringency wash described below to $49^{\circ} \mathrm{C}$ :

$\begin{array}{lc}20 \times \text { SSPE } & 180 \mathrm{ml} \text { (final conc. }=6 \times) \\ 10 \% \text { SDS } & 6 \mathrm{ml} \text { (final conc. }=0.1 \% \text { ) } \\ \text { Distilled water } & 414 \mathrm{ml} \\ \quad \text { Total } & 600 \mathrm{ml}\end{array}$


Wash the blot in enough wash solution to cover the blot thoroughly. Shake the blot while washing for $15 \mathrm{~min}$ at $49^{\circ} \mathrm{C}$. Remove the membrane, and blot it dry with absorbent paper. At this point, you may wish to check the blot with a portable radiation detection device; this will allow you to determine the effectiveness of the high-stringency wash.

High-stringency Wash

Preheat the high-stringency wash described below to $49^{\circ} \mathrm{C}$.

$\begin{array}{ll}6 \times \text { wash solution } & 200 \mathrm{ml}(\text { final conc. }=2 \times) \\ \text { Distilled water } & 400 \mathrm{ml} \\ \text { Total } & 600 \mathrm{ml}\end{array}$

Wash the blot as described above, except the time required is only $\sim 30 \mathrm{sec}$. If additional washing is required, repeat the high-stringency step, or a $1 \times$ wash can be used. When the blot has been washed correctly, the background on blank areas of the membrane should be $200 \mathrm{cpm}$ or less. The blot can then be quantified by the method of your choice.

\section{REFERENCES}

1. Murphy, L.D., C.E. Herzog, J.B. Rudick, A.T. Fojo, and S.E. Bates. 1990. Use of the polymerase chain reaction in the quantitation of mdr-1 gene expression. Biochemistry 29: 10351.

2. Noonan, K.E., C. Beck, T.A. Holzmayer, J.E. Chin, J.S. Wunder, I.L. Andrulis, A.F. Gazdar, C.L. Willman, B. Griffith, D.D. Von Hoff, and I.B. Roninson. 1990. Quantitative analysis of MDR1 (multidrug resistance) gene expression in human tumors by polymerase chain reaction. Proc. Natl. Acad. Sci. 87: 7160.

3. Park, O. and K.E. Mayo. 1991. Transient expression of progesterone receptor messenger RNA in ovarian granulosa cells after the preovulatory luteinizing hormone surge. Mol. Endocrinol. 5: 967.

4. Razin, E., K.B. Leslie, and J.W. Schrader. 1991. Connective tissue mast cell in contact with fibroblasts expresses IL-3 mRNA: Analysis of single cells by polymerase chain reaction. $J$. Immunol. 146: 981.

5. Svetic', A., F.D. Finkelman, Y.C. Jian, C.W. Dieffenbach, D.E. Scott, K.F. McCarthy, A.D. Steinberg, and W.C. Gause. 1991. Cytokine gene expression after in vivo primary immunization with goat antibody to mouse IgD antibody. J. Immunol. 147: 2391.

6. Morris, S.C., B. Hubbard, M. Gately, W.C. Gause, and F.D. Finkelman. 1993. Effects of interleukin-12 (IL-12) on an in vivo, T cell-dependent, humoral immune response. J. Immunol. 150: $45 \mathrm{a}$.

7. Yamamura, M., K. Uyemura, R.J. Deans, K. Weinberg, T.H. Rea, B.R. Bloom, and R.L. Modlin. 1991. Defining protective responses to pathogens: Cytokine profiles in leprosy lesions. Science 254: 277.

8. Elhers, S. and K.A. Smith. 1991. Differentiation of T cell lymphokine gene expression: The in vitro acquisition of T cell memory. J. Exp. Med. 173: 25.

9. Sambrook, J., E.F. Fritsch, and T. Maniatis. 1989. Molecular cloning: A laboratory manual, p. 31. Cold Spring Harbor Laboratory Press, Cold Spring Harbor, New York.

10. Berger, S.L., D.M. Wallace, R.S. Puskas, and V.H. Eschenfeldt. 1983. Reverse transcriptase and its associated ribonuclease $\mathrm{H}$ : Interplay of two enzymes, activity controls the yield of singlestranded complementary deoxyribonucleic acid. Biochemistry 22: 2365.

11. Svetic, A., K.B. Madden, X.D. Zhou, P. Lu, I.M. Katona, F.D. Finkelman, J.F. Urban, and W.C. Gause. 1993. A primary intestinal helminthic infection rapidly induces a gut-associated elevation of Th2-associated cytokines and IL-3. J. Immunol. 150: 3434.

12. Kawasaki, E.S. and A.M. Wang. 1989. Detection of gene expression. In PCR: Principles and application for DNA amplification (ed. H.A. Erlich), p. 89. M. Stockton Press, New York.

13. Diamond, S.L., L.C. McIntire, J.B. Sharefkin, C.W. Dieffenbach, K. Frasier-Scott, and S.G. Eskin. 1990. Tissue plasminogen activator mRNA levels increase in cultured human endothelial cells exposed to laminar sheer stress. J. Cell Physiol. 143: 364.

14. Lowe, T., J. Sharefkin, S.Q. Yang, and C.W. Dieffenbach. 1990. A computer program for selection of oligonucleotide primers for polymerase chain reaction. Nucleic Acids Res. 18: 1757.

15. Gendelman, H.E., R.M. Friedman, S. Joe, L.M. Baca, J.A. Turpin, G. Dveksler, M.S. Meltzer, and C.W. Dieffenbach. 1990. A selective defect of IFN production in HIV-infected monocytes. J. Exp. Med. 172: 1433. 
16. Dveksler, G., pers. comm.

17. Thryphronotis, G., I.M. Katona, W.C. Gause, and F.D. Finkelman. 1993. Germline and productive $C \epsilon$ gene expression during in vivo IgE responses. J. Immunol. 151: 4128.

18. Singer-Sam, J., M.O. Robinson, A.R. Bellvue, M.I. Simon, and A.D. Riggs. 1990. Measurement by quantitative PCR of changes in HPRT, PGK-1, PGK-2, APRT, MTase, and Zfy gene transcripts during mouse spermatogenesis. Nucleic Acids Res. 18: 1255.

19. Wynn, T.A., I. Eltoum, A.W. Cheever, F.A. Lewis, W.C. Gause, and A. Sher. 1993. Analysis of cytokine gene mRNA expression during primary granuloma formation induced by eggs of Schistosoma mansoni. J. Immunol. 151: 1430.

20. Svetic, A., Y.C. Jian, P. Lu, F.D. Finkelman, and W.C. Gause. 1993. Brucella abortus induces a novel cytokine gene expression characterized by elevated IL-10 and IFN-gamma in CD4+ T cells. Int. Immunol. 5: 877.

21. Ferre, F. 1992. Quantitative or semiquantitative PCR: Reality versus myth. PCR Methods and Applications 2: 1.

22. Gause, W.C., unpublished data.

23. Alard, P., O. Lantz, M. Sebagh, C.F. Calvo, D. Weill, G. Chavanel, A. Senik, and B. Charpentier. 1993. A versatile ELISA-PCR assay for mRNA quantitation from a few cells. BioTechniques 15: 730 .

24. Gilliland, G., S. Perrin, K. Blanchard, and H.F. Bunn. 1990. Analysis of cytokine mRNA and DNA: Detection and quantitation by competitive polymerase chain reaction. Proc. Natl. Acad. Sci. 87: 2725.

25. Kellogg, D.E., J.J. Sninsky, and S. Kwok. 1990. Quantitation of HIV-1 proviral DNA relative to cellular DNA by the polymerase chain reaction. Anal. Biochem. 189: 202.

26. Gause, W.C., unpubl.

27. Wang, M., M.V. Doyle, and D.F. Mark. 1989. Quantitation of mRNA by the polymerase chain reaction. Proc. Natl. Acad. Sci. 86: 9717.

28. Finkelman, F.D., A. Svetic', I. Gresser, C. Snapper, J. Holmes, P.P. Trotta, I.M. Katona, and W.C. Gause. 1991. Regulation by IFN- $\alpha$ of immunoglobulin isotype selection and lymphokine production in mice. J. Exp. Med. 174: 1179.

29. Murphy, L.D., C.E. Herzog, J.B. Rudick, A.T. Fojo, and S.E. Bates. 1991. Use of the polymerase chain reaction in the quantitation of mdr-1 gene expression. Biochemistry 29: 10351.

30. Becker-Andre, M. and K. Hahlbrock. 1989. Absolute mRNA quantification using the polymerase chain reaction (PCR). A novel approach by a PCR aided transcript titration assay (PATTY). Nucleic Acids Res. 17: 9437.

31. Gause, W.C., unpubl.

32. Kinoshita, T., J. Imamura, H. Nagai, and K. Shimotohno. 1992. Quantification of gene expression over a wide range by the polymerase chain reaction. Anal. Biochem. 206: 231.

33. Palliard, X., S.G. West, J.A. Lafferty, J.R. Clements, J.W. Kappler, P. Marrack, and B.L. Kotzin. 1991. Evidence for the effects of a superantigen in rheumatoid arthritis. Science 253: 325.

34. Choi, Y., B. Kotzin, L. Herron, J. Callahan, P. Marrack, and J. Kappler. 1989. Interactions of Staphylococcus aureus toxin "superantigens" with human T cells. Proc. Natl. Acad. Sci. 86: 8941.

35. Reiner, S.L., Z.-E. Wang, F. Hatam, P. Scott, and R.M. Locksley. 1993. Th1 and Th2 cell antigen receptors in experimental leishmaniasis. Science 259: 1457.

36. Siebert, P.D. and J.W. Larrick. 1993. PCR MIMICs: Competitive DNA fragments for use as internal standards in quantitative PCR. BioTechniques 14: 244.

37. Uberla, K., C. Platzer, T. Diamantstein, and T. Blankenstein. 1991. Generation of competitor DNA fragments for quantitative PCR. PCR Methods Applic. 1: 136.

38. Pannetier, C., S. Delassus, S. Darche, C. Sancier, and P. Kourilsky. 1993. Construction of recombinant RNA templates for use as internal standards in quantitative RT-PCR. BioTechniques 14: 70.

39. Li, B., P.K. Swhajpal, A. Khanna, H. Vlassara, A. Cerami, K. H. Tenzel, and M. Suthanthiran. 1991. Differential regulation of transforming growth factor beta and interleukin 2 genes in human T cells: Demonstration by usage of novel competitor DNA constructs in the quantitative polymerase chain reaction. J. Exp. Med. 174: 1259.

40. Gilliland, G., S. Perrin, and H.F. Bunn. 1990. Competitive PCR for quantitation of mRNA. In PCR protocols (ed. M.A. Innis, D.H. Gelfand, J.J. Sninsky, and T.J. White), p. 60. 


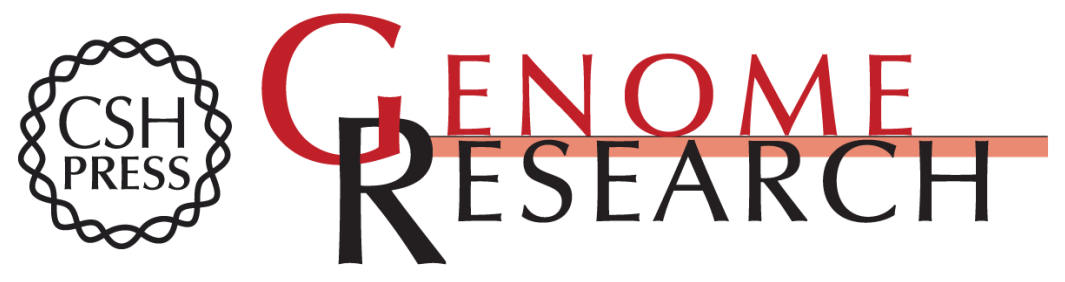

\section{The use of the PCR to quantitate gene expression.}

W C Gause and J Adamovicz

Genome Res. 1994 3: S123-S135

References This article cites 33 articles, 16 of which can be accessed free at:

http://genome.cshlp.org/content/3/6/S123.full.html\#ref-list-1

\section{License}

Email Alerting Receive free email alerts when new articles cite this article - sign up in the box at the Service top right corner of the article or click here.

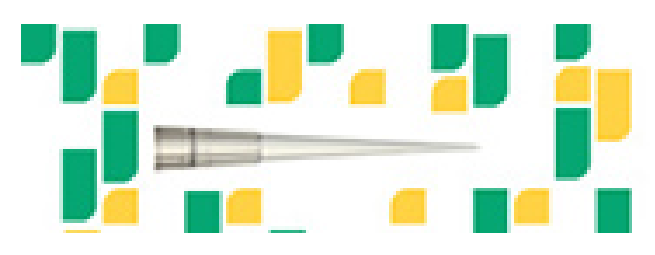

To subscribe to Genome Research go to: https://genome.cshlp.org/subscriptions 